\title{
On the presence of the subnarial foramen in Prestosuchus chiniquensis (Pseudosuchia: Loricata) with remarks on its phylogenetic distribution
}

\author{
LÚCIO ROBERTO-DA-SILVA ${ }^{1,2}$, MARCO A.G. FRANÇA ${ }^{3}$, SÉRGIO F. CABREIRA ${ }^{3}$, \\ RODRIGO T. MÜLLER ${ }^{1}$ and SÉRGIO DIAS-DA-SILVA ${ }^{4}$
}

\author{
${ }^{1}$ Programa de Pós-Graduação em Biodiversidade Animal, Universidade Federal de Santa \\ Maria, Av. Roraima, 1000, Bairro Camobi, 97105-900 Santa Maria, RS, Brasil \\ ${ }^{2}$ Laboratório de Paleontologia, Universidade Luterana do Brasil, Av. Farroupilha, \\ 8001, Bairro São José, 92425-900 Canoas, RS, Brasil \\ ${ }^{3}$ Laboratório de Paleontologia e Evolução de Petrolina, Campus de Ciências Agrárias, Universidade Federal \\ do Vale do São Francisco, Rodovia BR 407, Km12, Lote 543, 56300-000 Petrolina, PE, Brasil \\ ${ }^{4}$ Centro de Apoio à Pesquisa da Quarta Colônia, Universidade Federal de Santa Maria, Rua \\ Maximiliano Vizzotto, 598, 97230-000 São João do Polêsine, RS, Brasil
}

Manuscript received on July 1, 2015; accepted for publication on April 15, 2016

\begin{abstract}
Many authors have discussed the subnarial foramen in Archosauriformes. Here presence among Archosauriformes, shape, and position of this structure is reported and its phylogenetic importance is investigated. Based on distribution and the phylogenetic tree, it probably arose independently in Erythrosuchus, Herrerasaurus, and Paracrocodylomorpha. In Paracrocodylomorpha the subnarial foramen is oval-shaped, placed in the middle height of the main body of the maxilla, and does not reach the height of ascending process. In basal loricatans from South America (Prestosuchus chiniquensis and Saurosuchus galilei) the subnarial foramen is 'drop-like' shaped, the subnarial foramen is located above the middle height of the main body of the maxilla, reaching the height of ascending process, a condition also present in Herrerasaurus ischigualastensis. These results suggest that this structure might be phylogenetically important and further investigation with a large set of valid taxa is necessary to properly evaluate its importance among Archosauria.
\end{abstract}

Key words: Archosauria, extra cranial opening, Santa Maria Formation, Brazil.

\section{INTRODUCTION}

"Rauisuchia" is an important group of pseudosuchian archosaurs, including several taxa regarded as top terrestrial predators of their ecosystem during Triassic (Gower 2000, Nesbitt et al. 2013). As its phylogenetic status is controversial, it is herein

Correspondence to: Sérgio Dias-da-Silva

E-mail: paleosp@gmail.com placed in quotation (because it is considered paraphyletic by many authors, Nesbitt et al. 2013). Taxonomic problems and presence of convergent characters with other archosaurs could explain these alternative or divergent hypotheses (Desojo and Arcucci 2009). In spite of this, it provides valuable insights regarding radiation of Archosauria during the Mesozoic (Gower 2000). Actually, rauisuchians 
were widespread in Pangaea, except in the landmasses that now comprise Antarctica and Australia (Gower 2000, Brusatte et al. 2010, França et al. 2011, 2013, Nesbitt et al. 2013). "Rauisuchia" was an important group during the Early-Middle Triassic, significant to the diversification of Archosauria after the Permo-Triassic extinction (Nesbitt et al. 2013). The South America records include the following species: from Brazil, Prestosuchus chiniquensis Huene 1938, Rauisuchus tiradentes Huene, 1938, Procerosuchus celer Huene, 1938, Decuriasuchus quartacolonia França et al. 2011, and Dagasuchus santacruzensis Lacerda et al. 2015; from Argentina, Luperosuchus fractus Romer 1971, Saurosuchus galilei Reig 1959, Fasolasuchus tenax Bonaparte 1981 and Sillosuchus longicervix Alcober and Parrish, 1997 (Nesbitt et al. 2013). Despite their diversity and increasing number of documented contributions in the last 10 years regarding cranial osteology of "Rauisuchia", the presence or absence of a dermatocranial opening between premaxilla and maxilla - the subnarial foramen - is still open to debate (Gower 2000, Mastrantônio 2010, França et al. 2011, Nesbitt 2011, Lacerda 2012). This opening received different designations in the literature: subnarial fenestra/foramen by some (e.g. Chatterjee 1985, Galton 1985, Parrish 1993) or extra accessory antorbital fenestra by others (e.g. Sill 1974, Dawley et al. 1979, Benton 1986, Long and Murry 1995, Gower 2000, Langer 2004). According to Gower (2000), presence or absence of such feature is potentially phylogenetically informative for rauisuchians. Indeed, the subnarial foramen was accepted as a diagnostic character by Chatterjee (1985), Benton (1986), Long and Murry (1995), and Gower (2000). As a result, including Prestosuchus chiniquensis within "Rauisuchia" was considered problematic as it was considered devoid of such feature (Gower 2000). Recent descriptions confirmed the presence of the subnarial foramen in Prestosuchus chiniquensis, but its actual position and shape is open to inter- pretation due the supposed mobile joint between the premaxilla and maxilla (Mastrantônio 2010). Additionally, in cranial material of "Rauisuchia", this joint may have suffered taphonomic distortions (Nesbitt 2011, Lacerda 2012). The aims of this contribution are the evaluation of new evidence regarding presence, size, shape, and position of the subnarial foramen in Prestosuchus chiniquensis and discuss its implication for archosaurian phylogeny. The study is based upon a new nearly complete individual of $P$. chiniquensis from the municipality of Dona Francisca (central region of Rio Grande do Sul State, southern Brazil). The specimen (Fig. 1) is housed at the Universidade Luterana do Brasil (ULBRA-PVT-281). It comprises a large complete skull and a partial postcranial skeleton.

INSTITUTIONAL ABBREVIATIONS

CPEZ, Coleção de Paleontologia do Museu Walter Ilha, São Pedro do Sul, Rio Grande do Sul, Brazil; MCN, Museu de Ciências Naturais da Fundação Zoobotânica do Estado do Rio Grande do Sul, Brazil; PVL, Paleontologia de Vertebrados, Instituto "Miguel Lillo", San Miguel de Tucumán, Argentina; PVSJ, División de Paleontologia de Vertebrados del Museo de Ciencias Naturales y Universidad Nacional de San Juan, Argentina; SMNS, Staatliches Museumfür Naturkunde, Stuttgart, Germany; TTUP, Texas Tech University Paleontology collections, Lubbock, Texas, USA; ZPAL, Institute of Paleobiology, Polish Academy of Sciences, Warsaw, Poland; UFRGS, Universidade Federal do Rio Grande do Sul, Paleontologia de Vertebrados, Porto Alegre, Brazil; ULBRA, Universidade Luterana do Brasil, Coleção de Paleovertebrados, Canoas, Rio Grande do Sul, Brazil.

\section{SYSTEMATIC PALEONTOLOGY}

Archosauria sensu Gauthier 1986

Pseudosuchia sensu Sereno 2005

Loricata Merrem 1820 (sensu Nesbitt 2011)

Prestosuchus chiniquensis Huene 1938 


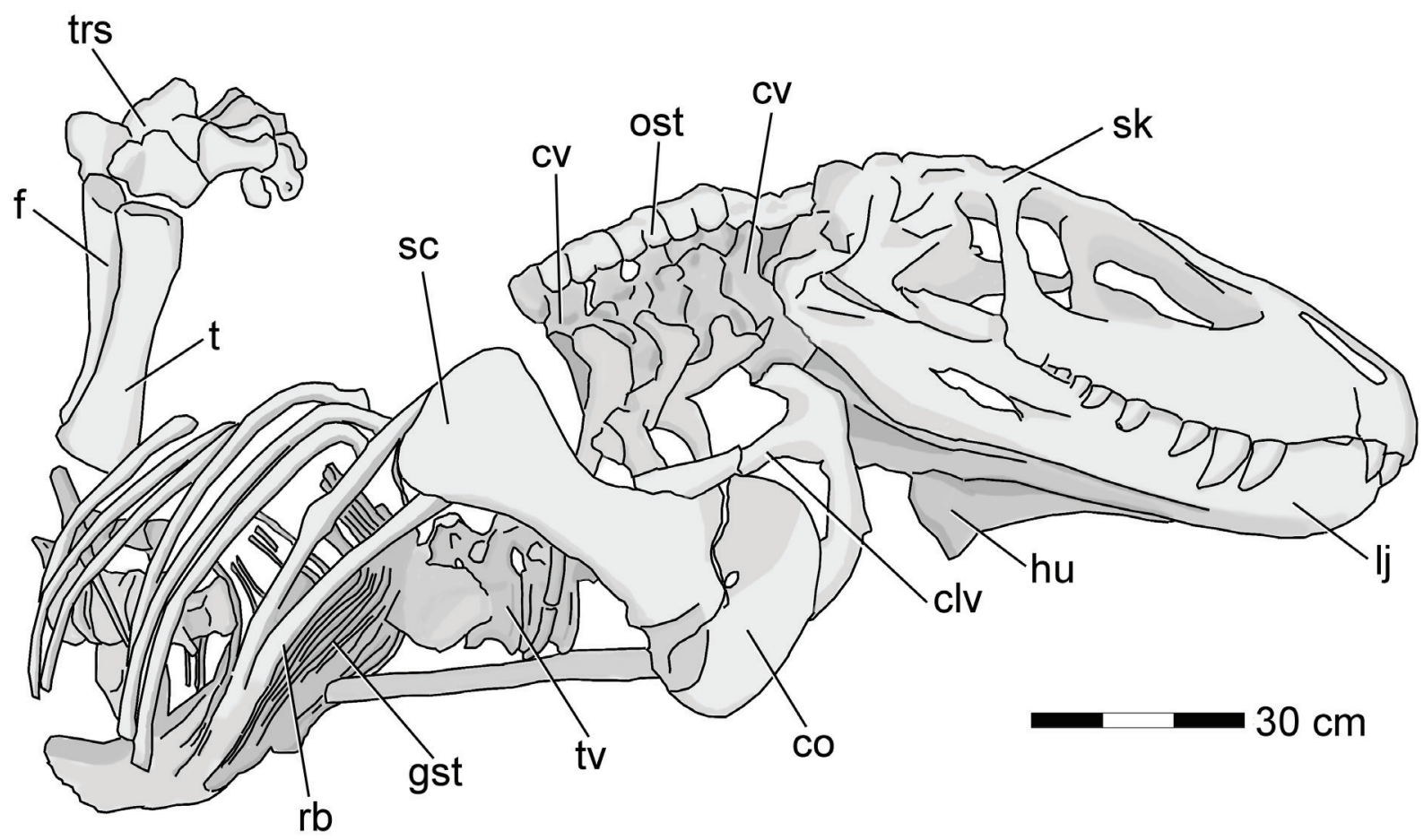

Figure 1 - Schematic drawing of ULBRA-PVT-281, a complete skull and a partial postcranial skeleton. Abbreviations: clv, clavicle; co, coracoid; cv, cervical vertebra; f, fibula; gst, gastralia; hu, humerus; lj, lower jaw; ost, osteoderm; rb, rib; sc, scapula; sk, skull; t, tibia; trs, tarsus; tv, trunk vertebra.

ULBRA-PVT-281 (Figs 1, 4, and 5a) is referred to $P$. chiniquensis based on the presence of two characters: (1) the presence of sharp leading from the glenoid to anteroventral corner of the coracoid (shared with Procerosuchus) and (2) anteroventrally directed ventral process of the squamosal (Nesbitt 2011). Additional diagnostic characters of ULBRAPVT-281 (still under preparation) will be provided in a full description elsewhere (Roberto-da-Silva in press).

\section{TYPE LOCALITY AND HORIZON}

ULBRA-PVT-281 was recovered in the "Posto de Gasolina" outcrop, nearby the main access to Dona Francisca city, central region of Rio Grande do Sul

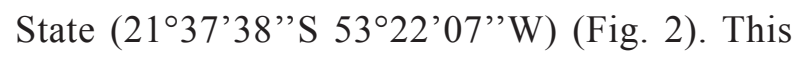
locality also had yielded other specimens ascribed to Loricata including Decuriasuchus quartacolonia (França et al. 2011, 2013); and additional material referred to Prestosuchus chiniquensis (UFRGSPV-0629-T; Mastrantônio 2010).

According to Zerfass et al. (2003), LadinianRhaetian strata from the Rio Grande do Sul are attributed to three depositional sequences (Santa Maria 1, 2 and 3). ULBRA-PVT-281 was collected in levels from the Santa Maria 1 (Pinheiros-Chiniquá sequence, sensu Horn et al. 2014) characterized by the prevalence of reddish mudstones with sub aerial exposure and carbonate concretions (Rubert and Schultz 2004). The dicynodont Dinodontosaurus and the cynodont Massetognathus ochagaviae also come from the same outcrop and stratigraphic level of ULBRA-PVT-281.Together those synapsids characterize the Dinodontosaurus Assemblage Zone (Pavanatto et al. 2015). Such Assemblage Zone is inserted at the base of the Santa Maria 1 (Pinheiros-Chiniquá) Sequence, and this is dated as Ladinian-early Carnian age from biostratigraphic 


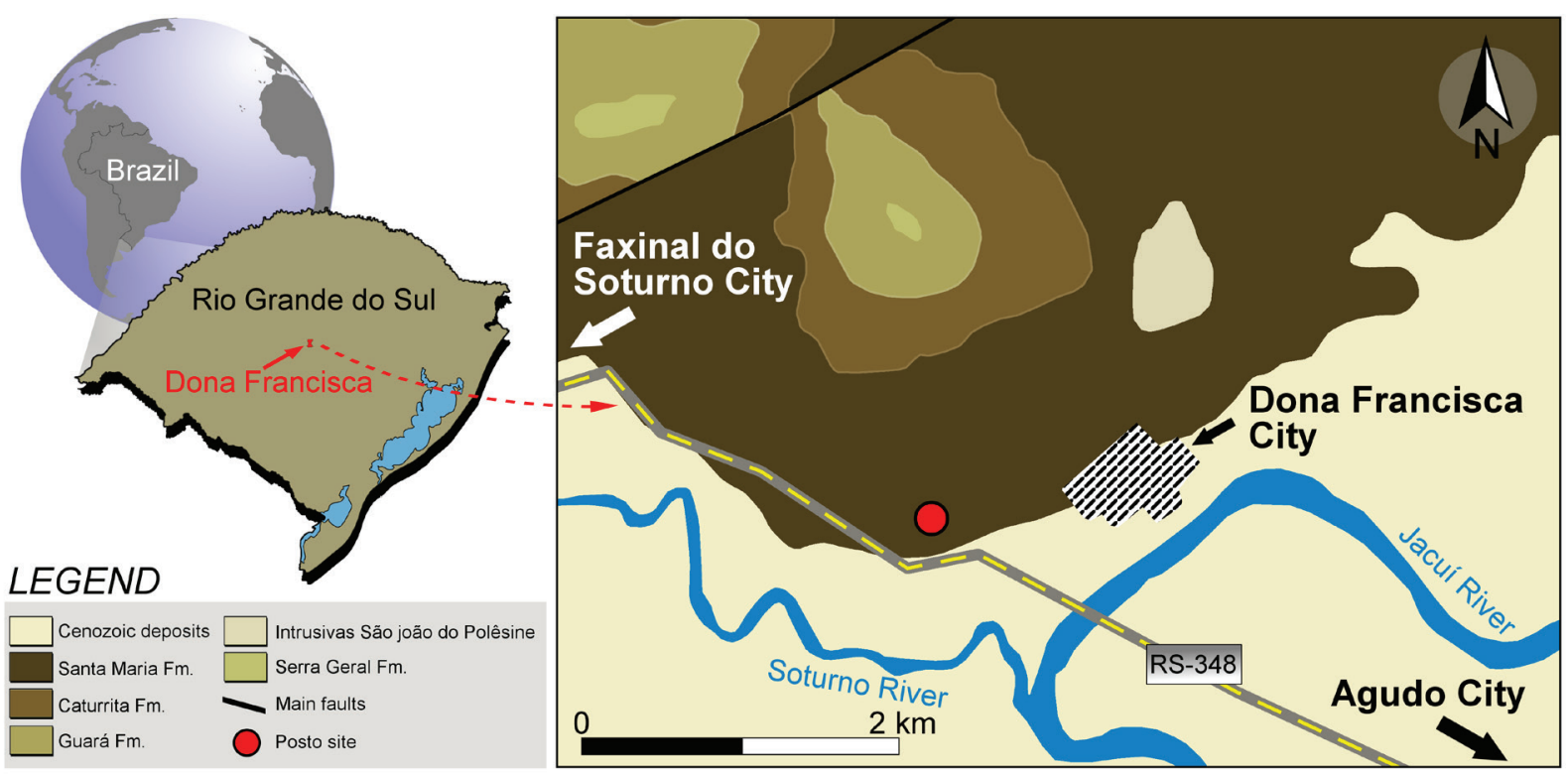

Figure 2 - Location of the "Posto Site" in the municipality of Dona Francisca in the Rio Grande do Sul State, Southern Brazil. Geological units according to Zerfass et al. (2007).

data (Zerfass et al. 2003, Soares et al. 2011, Desojo et al. 2011, Horn et al. 2014) (Fig. 3).

\section{DESCRIPTION}

As a detailed description of ULBRA-PVT-281 will be provided elsewhere, herein we focus solely on the description of the subnarial foramen and its surrounding bone elements (maxilla and premaxilla), discussing its relevance in archosaurian studies (Fig. 4). The subnarial foramen is 'droplike' shaped, and is bordered by the main body and ascending process of the maxilla.

Premaxilla. The right premaxilla of ULBRAPVT-281 is exposed in lateral view. It is labiolingually compressed, with a subquadrangular main body in lateral view, resembling $P$. chiniquensis specimens (UFRGS-PV-0629-T, UFRGS-PV0156-T, BSPG AS XXV 28). In contrast, Decuriasuchus quartacolonia, Polonosuchus silesiacus (ZPAL/AbIII-563), Fasolasuchus tenax (PVL3850), Batrachotomus kupferzellensis (SMNS80260), and Postosuchus kirkpatricki, this bone shows a subrectangular shape (França et al. 2013). However, intraspecific variations are recognized for Saurosuchus galilei (either subquadrangular or subrectangular, see Alcober 2000). In Luperosuchus fractus the premaxilla ranges from slightly oval to quadrangular (Desojo and Arcucci 2009).

The premaxilla possesses two long dorsoposteriorly oriented projections: the anterodorsal and posterodorsal (= postnarial) processes. In ULBRAPVT-281, both processes meet the nasal, forming both anterior and posterior margins of the external naris. Unlike some "Rauisuchia" (e.g. Batrachotomus kupferzellensis), in ULBRA-PVT-281 the maxilla does not participate in the external naris. The posteroventral margin of the posterodorsal process contacts the ascending process of the maxilla and forms an angle of $55^{\circ}$, in relation to the body of premaxilla, contrasting with $45^{\circ}$ observed in Decuriasuchus quartacolonia (França et al. 2013). The anterodorsal process is semicircular in crosssection. The anterior margin of the main body of the premaxilla is straight and vertical (not sinuous). 


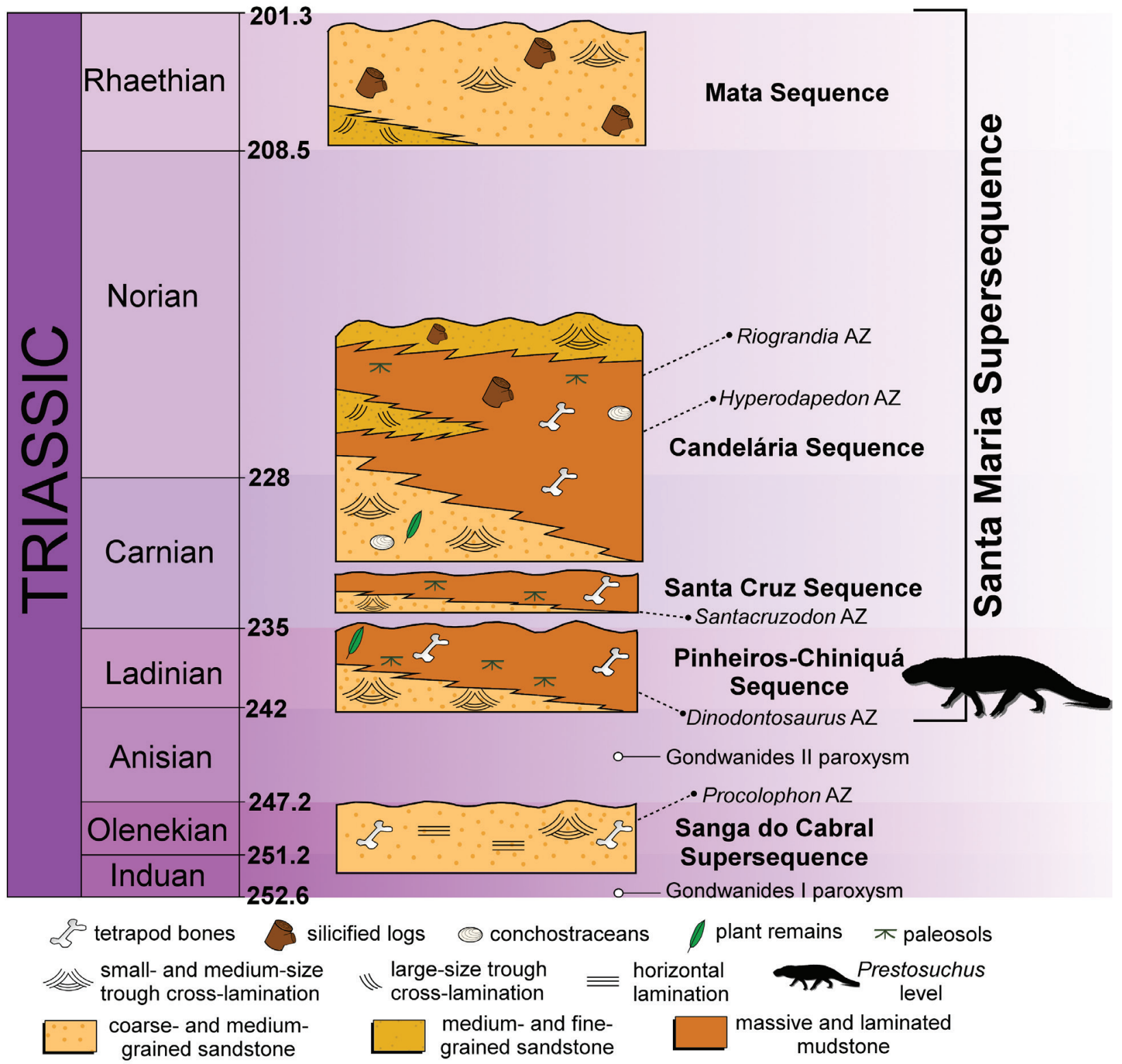

Figure 3 - Stratigraphic framework of the Triassic package from southern Brazil showing the Riograndia AZ; Hyperdapedon AZ; Santracruzodon AZ; Dinodontosaurus AZ; and Procolophon AZ. Rauisuchian outline in black indicates Prestosuchus chiniquensis level. Modified from Zerfass et al. (2003), Desojo et al. (2011) and Horn et al. (2014). Geological timescale follows Gradstein et al. (2012).

The contact between premaxilla and maxilla is slightly sigmoidal. The ventral margin of the premaxilla is horizontal, bearing four teeth. This number of teeth is shared with several loricatans, such as Saurosuchus, Fasolasuchus, Batrachotomus, Postosuchus, Polonosuchus, and other specimens of Prestosuchus (UFRGS-PV-0629-T; UFRGS-
PV-0156-T) (Barberena 1978, Bonaparte 1981, Long and Murry 1995, Gower 1999, Weinbaum 2002, Sulej 2005, Mastrantônio 2010). The medial surface is not visible due to lower jaw occlusion, precluding morphological description of the medial surface, interdental plates and palatal process of premaxilla. 


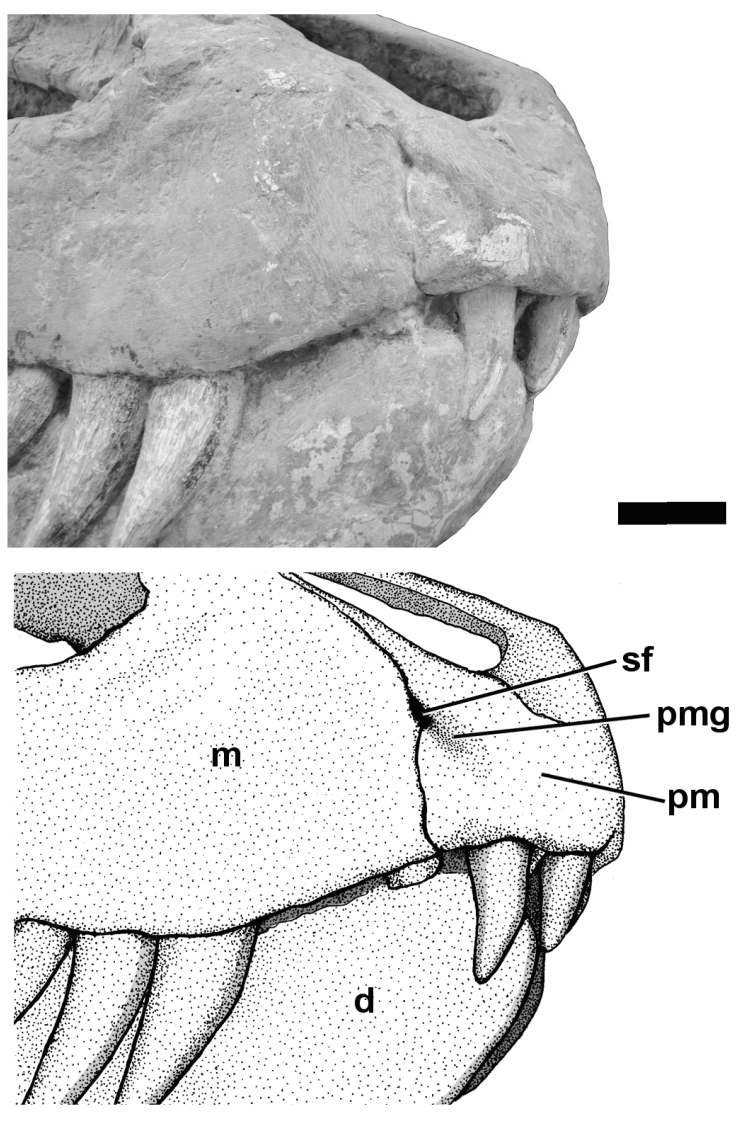

Figure 4 - Photograph and interpretative drawing depicting the rostral region of ULBRA-PVT-281. Abbreviations: d, dentary; $\mathrm{mx}$, maxilla; pmg, premaxillar groove; pmx, premaxilla; sf, subnarial foramen. Scale bar equals $10 \mathrm{~cm}$.

Maxilla. The main body of maxilla extends over the lateral surface of the skull. The lateral surface bears slightly rugosities and foramina close to its ventral margin. The maxilla articulates with the premaxilla, nasal, jugal, and lacrimal, as in nearly all archosauromorphs (França et al. 2013). The maxilla forms the ventral and anterior margin of the antorbital fenestra in ULBRAPVT-281. In Prestosuchus chiniquensis, as well as ULBRA-PVT-281, the ventral margin of the antorbital fenestra does not possess a ridge, unlike Postosuchus (Long and Murry 1995: fig 122, Alcober 2000, Weinbaum 2002) and Rauisuchus (Lautenschlager and Rauhut 2014). The ventral margin of the maxilla of ULBRA-PVT-281 is convex, with at least eleven teeth (eight visible elements and approximately three more alveoli present). In other $P$. chiniquensis specimens the number of alveoli is variable. At least eleven are present in UFRGS-PV-0156-T whereas thirteen are present in UFRGS-PV-0629-T (Barberena 1978; Mastrantônio 2010). This is in contrast to Decuriasuchus in which at least 17 alveoli are observed (França et al. 2011).

Subnarial foramen of Prestosuchus chiniquensis. In the first description of a complete skull of Prestosuchus chiniquensis (UFRGS-PV0156T) by Barberena (1978), the subnarial foramen was not recognized and it was acknowledged as absent. Nesbitt (2011), in his extensive phylogenetic analysis of archosaurs, also argued that this structure is absent in Prestosuchus chiniquensis and Saurosuchus galilei, drawing attention to taphonomic distortion in both species. Based upon new material, this structure was recently mentioned as present in Prestosuchus chiniquensis (UFRGS-PV-0629-T; Mastrantônio 2010). However, França et al. (2013) suggested that the subnarial foramen was also present in the specimen described by Barberena (1978 - UFRGS-PV-0156-T) regardless the unquestionable fact that this particular specimen is clearly taphonomically distorted. Accordingly, Mastrantônio (2010) sustained that the shape of this structure should be considered with caution as a probable movable joint between maxilla and premaxilla that could have been distorted in UFRGS-PV-0156T during taphonomic processes. The present specimen (ULBRA-PVT-281, ascribed to $P$. chiniquensis) does not present any visible sign of taphonomic distortion and clearly possess the subnarial foramen, which is well evident between the maxillary/premaxillary suture (Fig. 5a). Both shape and position of the subnarial fenestra varies in rauisuchians as relative medium-sized foramina occur in Prestosuchus and Postosuchus, whereas a large fenestra is observable in Luperosuchus 
a

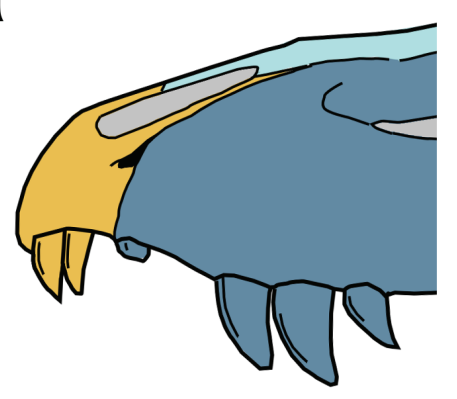

d

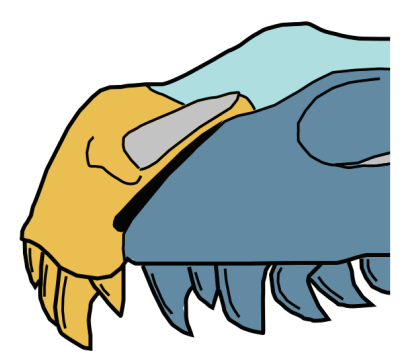

g

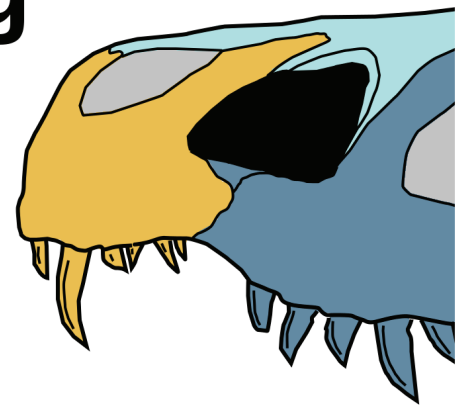

b

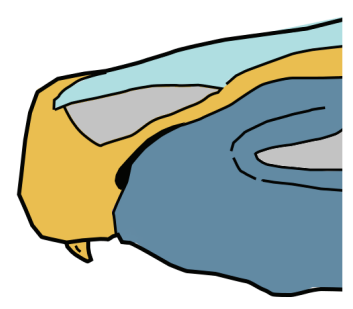

C

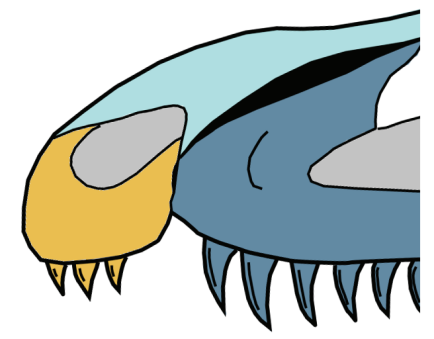

e

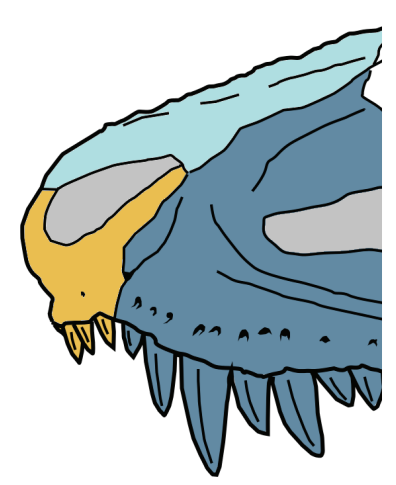

f

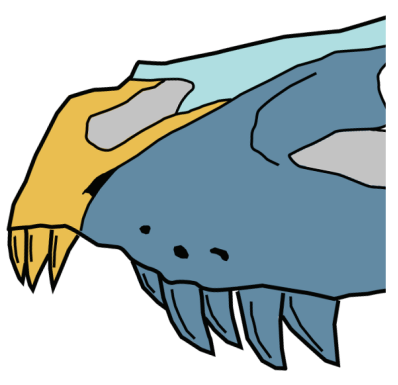

$\mathbf{h}$

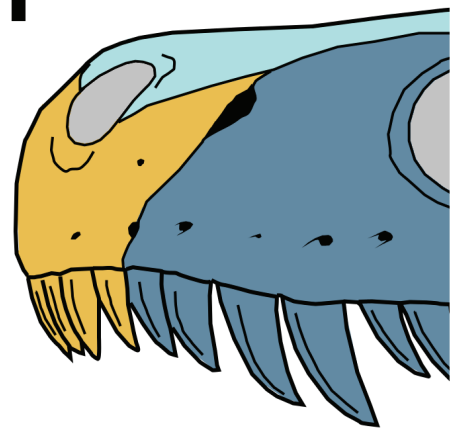

maxilla i

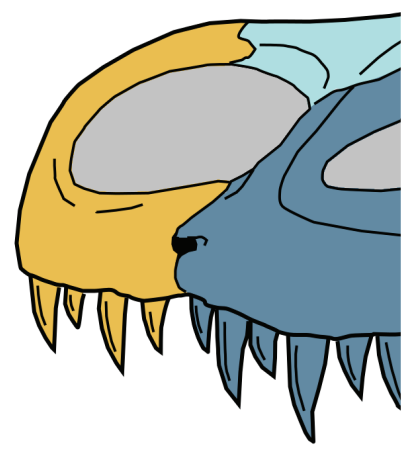

nasal

Figure 5 - Schematic drawing depicting the rostral region of selected archosauriforms in left lateral view. The subnarial fenestra is depicted in black. a, Prestosuchus chiniquensis ULBRA-PVT-281; b, Saurosuchus galilei; c, Luperasuchus fractus; d, Decuriasuchus quartacolonia; e, Postosuchus kirkpatricki; f, Prestosuchus chiniquensis UFRGS-PV-0629-T; g, Shansisuchus shansisuchus; h, Herrerasaurus ischigualastensis; i, Batrachotomus kupferzellensis.

fractus (Fig. 5c). In the latter taxon, a taphonomic or disarticulated origin of fenestra is questionable, added to uncommon position of fenestra. Other remarkable feature of ULBRA-PVT-281 is the presence of a well-marked groove, which starts at the premaxilla-maxilla suture and runs anteroventraly to the premaxillary body. Previously, this premaxillary groove was not mentioned to any other known specimen of Prestosuchus. However, at this point taphonomic artifact cannot be ruled out regarding this structure, as both taphonomically distorted specimens UFRGS-PV-0156-T and 0629-T (ascribed to $P$. chiniquensis) presents this feature in one side of the skull, whereas, in the 
other side, it is apparently absent. The premaxillary groove is also absent in many other rauisuchians, such as Luperosuchus fractus, Batrachotomus kupferzellensis, Postosuchus kirkpatricki, Decuriasuchus quartacolonia, Rauisuchus tiradentes and Saurosuchus galilei (Alcober 2000, Weinbaum 2002, Lautenschlager 2008, Desojo and Arcucci 2009, França et al. 2011, 2013). Therefore, further examination of more specimens attributable to $P$. chiniquensis is necessary in order to solve this question. If it is not taphonomic, the premaxillary groove would represent an autapomorphic character of $P$. chiniquensis. This groove differs from those described by Nesbitt (2011) for Revueltosaurus and Erythrosuchus, because, in these taxa, the groove is posteriorly directed on the maxilla. Conversely, in Prestosuchus chiniquensis (ULBRA-PVT-281) this groove is anteriorly directed on the premaxilla.

In Prestosuchus chiniquensis the subnarial foramen is a drop-like shaped opening located between premaxilla and maxilla, both equally contributing to its borders in ULBRA-PVT-281. The height of the foramen occupies part of the main bodies and posterodorsal processes of maxilla/premaxilla, as in Saurosuchus galilei (Fig. 5b) (Alcober 2000). In Saurosuchus galilei, the subnarial foramen is slit-like in juvenile specimens (Alcober 2000). According to Nesbitt (2011), this structure would be absent in this taxon and those alleged openings would be artifact of preservation. However, in the holotype of S. galilei (PVL 2068), considered an adult individual, there is a subnarial foramen, in spite of the fact that this specimen shows signs of taphonomic distortion in some degree. Its morphology and position is quite similar to that of ULBRA-PVT-281. In Batrachotomus kupferzellensis, Fasolasuchus tenax, Effigia okeeffeae, Shuvosaurus inexpectatus, Qianosuchus mixtus, Lotosaurus adentus, and Postosuchus kirkpatricki the subnarial foramen is oval, located at the average height regarding the main body of maxilla, not reaching the height of the posterodorsal process (Chatterjee 1985, Bonaparte 1981, Gower 1999, Nesbitt and Norell 2006, Weinbaum 2011). Additionally, in Decuriasuchus quartacolonia the subnarial foramen occupies part of main body of maxilla and reaches the base of the ascending process, resembling Prestosuchus chiniquensis and Saurosuchus galilei (Alcober 2000, França et al. 2013). Despite the vast literature regarding "Rauisuchia", occurrence/description of the subnarial foramen is dubious in some taxa. For instance, in Polonosuchus silesiacus (Sulej 2005) the presence/absence of such feature is doubtful due the lack of a preserved premaxilla and maxilla in articulation.

\section{PHYLOGENETIC ANALYSIS}

Phylogenetic status and inner relationships of "Rauisuchia" are still open to debate, in spite of many new descriptions and revisions (Brusatte et al. 2010, Nesbitt 2011, Lautenschlager and Rauhut 2014). Different results created many challenges to provide a satisfactory phylogenetic definition to this group (Nesbitt et al. 2013). Presence/absence of the subnarial foramen has been previously considered useful for taxonomical purposes; however, its phylogenetic utility was also challenged. Gower (2000) pointed out that using this structure is problematic due to its highly homoplastic distribution among Archosauria. Conversely, previous contributions claimed that the presence of the subnarial foramen is phylogenetically important to some rauisuchians (Benton and Clark 1988, Parrish 1993, Juul 1994). Nesbitt (2011) provided a comprehensive phylogenetic analysis of Archosauria, scoring the subnarial foramen (either absent or present and the contribution of maxilla and premaxilla to its borders) in his data-matrix (character 12), but did not recognize its presence in Prestosuchus chiniquensis. In this contribution, we change the scores of some operational taxonomic units (OTUs) regarding such character in the dataset of 
Butler et al. (2014), which is a modified version of the matrix presented by Nesbitt (2011). Originally, Prestosuchus chiniquensis and Saurosuchus galilei were scored as lacking the subnarial foramen (0). In this contribution, in both species the subnarial foramen is scored as present and limited by both maxilla and premaxilla (character state 1). The herrerasaurid Herrerasaurus ischigualastensis bears two openings along the suture between premaxilla and maxilla (Sereno and Novas 1993), in which the more ventral is topologically similar to saurischian dinosaurs (e.g. Efraasia minor, Plateosaurus engelhardti, and Eoraptor lunensis), whereas the larger and more dorsal opening is topologically equivalent to that present in pseudosuchians (Fig. 5h). Therefore, among evaluated saurischians, just Herrerasaurus ischigualastensis is scored here with the condition (1). In the remaining saurischians, this structure is considered absent (character state 0 ). Another modification in the dataset of Butler et al. (2014) includes the addition of a new character (414) related to the position of the subnarial foramen. Such character includes two states: (0) in the middle average height regarding the maxillary body, not reaching the ascending process; (1) above the middle height of the main body of the maxilla, reaching at least the base of the ascending process. Those taxa without subnarial foramen are encoded as inapplicable "-". The subnarial foramen of Crocodylomorpha is considered inapplicable, as it is an artifact resulting from the insertion of the caniniform teeth in the maxilla, not being homologous to the subnarial foramen (the full codification of the new character is in Appendix I).

The analysis was performed under equally weighted parsimony using the software TNT 1.1 (Goloboff et al. 2003, 2008). A traditional search with 100 replicates of Wagner trees (with random addition sequence) followed by TBR branch-swapping (holding 10 trees per replicate) was performed. The analysis recovered 81 most parsimonious trees (MPTs) of 1312 steps each (consistence index $=0.369$; retention index $=0.771$ ). Bremer and bootstraps values (1000 replicates) were also obtained from TNT v 1.1 (Goloboff et al. 2008). Decuriasuchus quartacolonia (Fig. 5d) was not included in this dataset because it is currently under review by M.A.G.F.

\section{DISCUSSION}

In spite of the discussion regarding the subnarial fenestra/foramen in archosaurs, there is no consensus about its function. According to Gower (2000), two hypotheses are in dispute, the first would be related to the air sinus system and the second to either blood vessels or nerve transmission. However, no evidence has been provided to corroborate either. In Batrachotomus kupferzellensis (Gower 1999), Saurosuchus galilei (Alcober 2000), Prestosuchus chiniquensis (UFRGS-PV0156T, Barberena 1978; UFRGS-PV-0629-T, Mastrantônio 2010; CPEZ239b, Lacerda 2012; UFRGS-PV-0152-T, Raugust 2014), Postosuchus kirpatricki (Weinbaum 2011), and Luperosuchus fractus (Desojo and Arcucci 2009), the subnarial foramen is only mentioned as present and no additional information is provided for this structure.

Despite the possible phylogeneticimportance of the subnarial foramen, recent contributions discuss inconsistencies and alternative interpretations regarding this structure (Gower 2000, Mastrantônio 2010, Lacerda 2012). According to Gower (2000), its presence is homoplastic amongst "Rauisuchia". Additionally, a similar opening occurs in other nonrauisuchian archosaurs, such as the erythrosuchid Shansisuchus shansisuchus, the herrerasaurid dinosaur Herrerasaurus ischigualastensis (Sereno and Novas 1993), and pterosaurs (e.g. Dorygnathus banthensis) (Ösi 2010). Moreover, in Shansisuchus shansisuchus, for instance, the subnarial foramen is formed by a bifurcation of the anteroventral process of the nasal and extends ventrally interrupting the premaxilar/maxilar contact (Fig. 5g). Therefore, 
this configures an analogous condition in relation to the feature present in "rauisuchians". In addition, this structure was recognized as an autapomorphy for the saurischian dinosaur Herrerasaurus ischigualastensis (Sereno and Novas 1993). So, it would have been convergently developed in taxa other than rauisuchians (Desojo and Arcucci 2009, Lacerda 2012). On the other hand, the subnarial foramen was recognized as a diagnostic character of "Rauisuchia" (Chatterjee 1985, Gower 2000, Lautenschlager 2008, Lautenschlager and Rauhut 2014). Both presence and shape of the subnarial foramen is uncertain in many rauisuchians, as the majority of specimens are incomplete or with disarticulated bones. Additionally, the shape of the subnarial foramen would be subject to both taphonomic distortion and ontogenetic variation as well (Alcober 2000, Nesbitt 2011). Based on specimens of Saurosuchus galilei, Alcober (2000) suggested that the subnarial fenestra is only present in juvenile individuals, fully closing in adults. However, this statement is dubious as the ontogenetic state of $S$. galilei specimens is uncertain. Actually, the two specimens of Saurosuchus galilei (PVL 2062 and PVSJ 32, respectively putative adult and young individuals) show an evident opening between premaxilla and maxilla. In addition, putative adult specimens of Prestosuchus chiniquensis (UFRGS-PV-0156-T; UFRGS-PV-0629-T; ULBRA-PVT-281) possess this structure. There are also differences between UFRGS-PV-0629-T and ULBRA-PVT-281. In the first, the subnarial foramen is slit-like and elongated (Mastrantônio 2010), whereas in ULBRA-PVT-281 it is "drop-like" shaped. According to Mastrantônio (2010), these differences can be explained by the presence of kinesis between maxilla and premaxilla (a mobile joint between these two bones). In both cases, Mastrantônio (2010) argued that this joint would show distortions due to diagenesis, resulting in different shapes and sizes. Given the accentuated lateral deformation of UFRGS-PV-0629-T, we consider that the elongated shape of its subnarial foramen is an artifact of preservation (Fig. 5f).

The presence of relative movement among intracranial joints is discussed by many paleontologists. Different types of kinesis were defined according to the joint location in dorsal parts of the skull (Versluys 1910, 1912, 1936, Holliday and Witmer 2008). In extant taxa, as in most lizards, there are three types of cranial kinesis: mesokinesis (between frontal/parietal), metakinesis (quadrate/paroccipital) and pleurokinesis (occipital condyle laterally) (Rieppel and Zaher 2001). So far, extant taxa lack mobility between maxilla and premaxilla. Additionally, in several extant lineages, such as turtles, crocodilians, and Sphenodon, cranial kinesis is totally absent (Iordansky 1990, Holliday and Witmer 2008). In neither case, a kinetic joint between premaxilla and maxilla was mentioned by the aforementioned authors. Moreover, according to Holliday and Witmer (2008), an animal may exhibit morphological features suggestive of intracranial mobility but not necessarily demonstrate significant functional mobility in vivo. Based upon these arguments, we state that a kinetic joint between premaxilla and maxilla is possible only if new data were obtained.

In Postosuchus kirkipatricki there is an excavation (visible in medial view) that starts in the premaxilla and ends in the maxilla. According to Chatterjee (1985) it would serve to accommodate the Jacobson's organ (also called vomeronasal organ), a chemoreceptor which is part of the olfactory system of amphibians, reptiles, and mammals, although it does not occur in all tetrapod groups (Rehorek et al. 2000). Probably, due to the presence of a Jacobson's organ there would be a movable premaxillary/maxillary joint in this taxon. However, other authors (Sill 1974, Bonaparte 1981, Witmer 1995, Gower 1999, Sulej 2005, Weinbaum 2011) do not agree with the presence of this organ in Postosuchus. In some basal archosauriforms, like Euparkeria capensis (Ewer 1965), the anterior 
region of lateral surface of maxilla bears a foramen. Most rauisuchians have a rostrolateral foramen on the anterior surface of maxilla, as Decuriasuchus quartacolonia (França et al. 2013), whereas others also have a rostromedial foramen, as Polonosuchus and Teratosaurus (Sulej 2005). The presence of these structures in taxa with distinct affinities indicate that this region would be the end extremity for blood vessels or nerve transmission, independently if subnarial foramen is present.

The inclusion of the new character in the phylogenetic analysis did not change the topology of
"Rauisuchia" presented by Butler et al. (2014) and the results allow the proposal of the likely evolutionary pathway for the subnarial foramen among paracrocodylomorphs (Fig. 6). The presence of the subnarial foramen probably begins in the common ancestor of Paracrocodylomorpha, in which the small subnarial foramen is oval shaped in average height regarding the main body of maxilla, not reaching the base of the ascending process [414(0)], occurring in Qianosuchus mixtus, Lotosaurus adentus, Effigia okeeffeae, Shuvosaurus inexpectatus, Batrachotomus kupferzellensis, Fasolasuchus
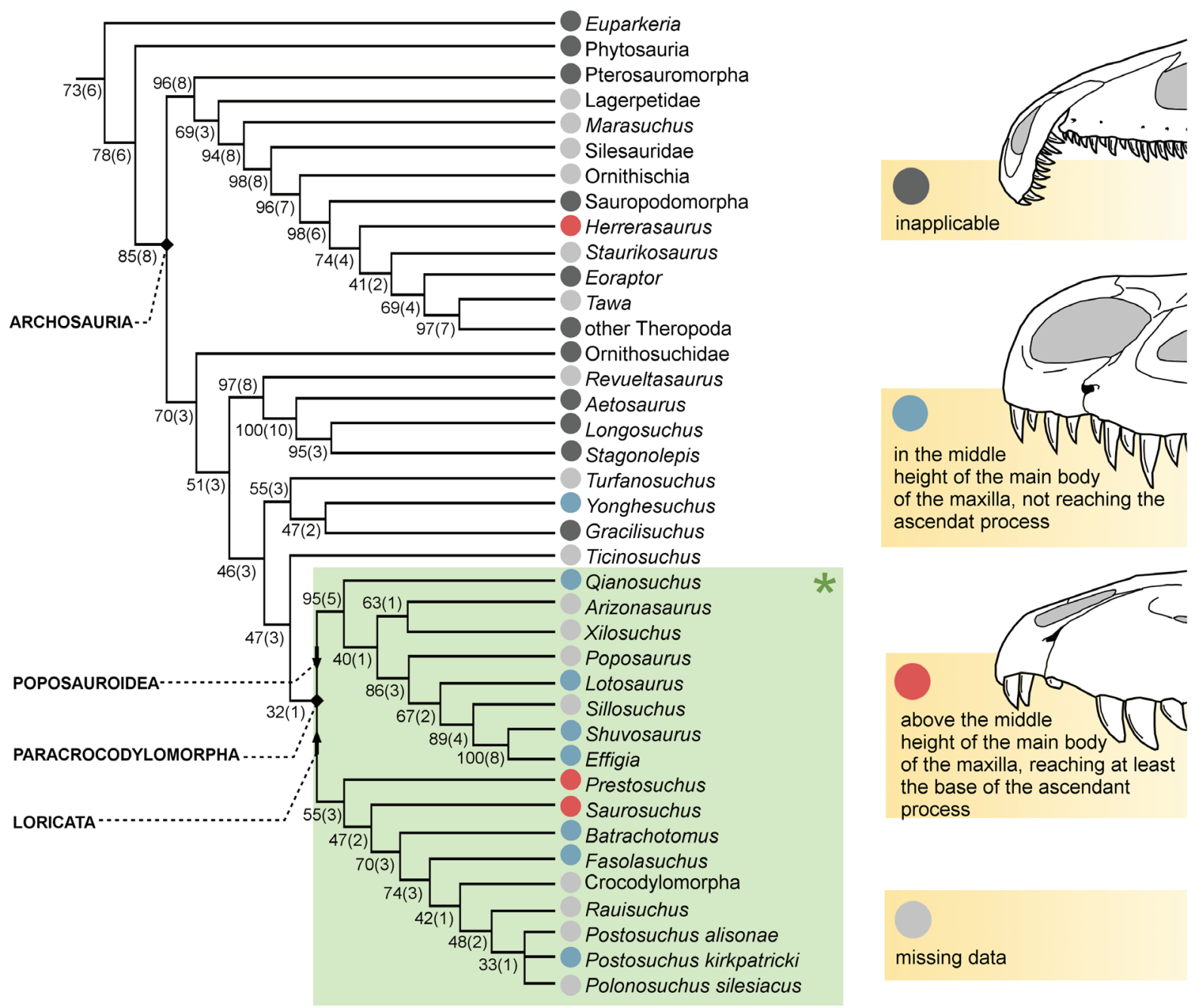

ascendat process
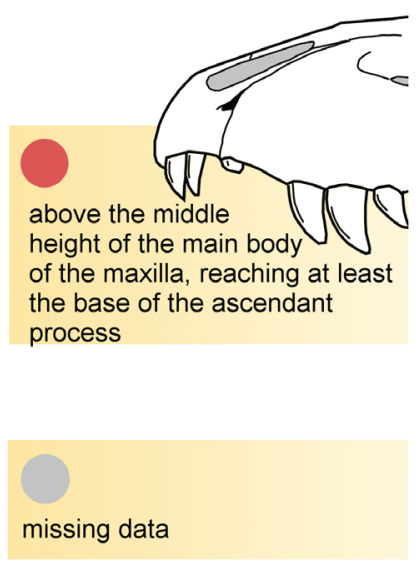

* Average height regarding the maxillary body, not reaching the ascendant process is inferred for Paracrocodylomorpha.

Figure 6 - Simplified strict consensus of 81 MPTs depicting the distribution of the new character among the OTUs. Numbers associated with nodes represent Bootstrap values and Bremer support (between parenthesis). 
tenax, and Postosuchus kirkpatricki (Fig. 5e). In basal loricatans from South America, Prestosuchus chiniquensis and Saurosuchus galilei, the subnarial foramen presents a new condition, related to its position: located above the middle height of the main body of the maxilla, reaching the base of the ascending process [414(1)]. Although not revealed in this analysis, this could suggest the presence of a less inclusive monophyletic group composed of some rauiuchians from Gondwana, as Prestosuchus, Saurosuchus and, possibly, Decuriasuchus, a hypothesis to be further evaluated. Considering only the pseudosuchian lineage, the subnarial foramen is shared by several pseudosuchian taxa other than Aetosauria, Crocodylomorpha, Gracilisuchidae or Ornithosuchidae (e.g. Nesbitt 2011). In this context, the presence of the subnarial foramen is a possible synapomorphy of Paracrocodylomorpha, being small, oval-shaped and restricted to main body of maxilla (Fig. 6). This condition is retained in Poposauroidea, but modified to drop-like, occupying the main body and ascending process of maxilla in basal Loricata, as Prestosuchus and Saurosuchus. Subsequently, the condition is reversed to a small oval-shaped fenestra in the clade including Batrachotomus, Fasolasuchus and Rauisuchidae.

Despite the close geographic distribution of Prestosuchus and Saurosuchus, as well as several shared characteristics including the presence and shape of subnarial foramen, our phylogenetic analysis did not recover them as sister taxa . Concluding, the results presented here suggest that there is a phylogenetic signal linked to the presence and position of the subnarial foramen in Archosauria. However, the lack of knowledge regarding its presence in several fragmentary and badly-preserved taxa is an obstacle to the understanding of the importance of this structure among this large group of Archosaurs, stressing the necessity of discover of more complete and better preserved specimens to clarify this issue.

\section{ACKNOWLEDGMENTS}

We thank the Fundação de Apoio à Tecnologia e Ciência (FATEC - process 3.01.0046) for the financial support to LRS; the Conselho Nacional de Desenvolvimento Científico e Tecnológico (CNPq) for the research grant to SDS (process 301801/20126); the Coordenação de Aperfeiçoamento de Pessoal de Nivel Superior (CAPES) for the scholarship to RTM; and the Fundação de Amparo à Ciência e Tecnologia do Estado de Pernambuco (FACEP) (process APQ-0165-2.04/14) for the financial support to MAGF. We thank the Willi Hennig Society, for the gratuity of TNT software. We also thank Martin Ezcurra and an anonymous referee for their valuable suggestions that greatly improved the manuscript.

\section{REFERENCES}

ALCOBER O. 2000. Redescripiton of the skull of Saurosuchus galilei (Archosauria: Rauisuchidae). J Vert Paleontol 20: 302-316.

BARBERENA MC. 1978. A huge tecodont skull from the Triassic of Brazil. Pesquisas 9: 62-75.

BENTON MJ. 1986. The Late Triassic reptile Teratosaurus- a rauisuchian, not a dinosaur. Paleontology 29: 293-301.

BENTON MJ and CLARK J. 1988. Archosaur phylogeny and the relationships of the Crocodilia. p. 289-332, 11 figs. In: Benton MJ (Ed), The phylogeny and classification of the tetrapods. Vol. I. Amphibians, reptiles, birds. Clarendon Press, Oxford, 377 p.

BONAPARTE JF. 1981. Descripcion de Fasolasuchus tenax y su significado em la sistemática y evolution de los Thecodontia. Revista del MACN "Bernardino Rivadavia" 3: $55-101$.

BRUSATTE SL, BENTON MJ, DESOJO JB and LANGER MC. 2010. The higher-level phylogeny of Archosauria (Tetrapoda: Diapsida). J Syst Palaeontol 8(1): 3-47.

BUTLER RJ, SULLIVAN C, EZCURRA MD, LIU J, LECUONA A AND SOOKIAS RB. 2014. New clade of enigmatic early archosaurs yields insights into early pseudosuchian phylogeny and the biogeography of the archosaur radiation. Evol Biol 14: 128.

CHATTERJEE S. 1985. Postosuchus, a new thecodontian Reptile from the Triassic of Texas and the origin of Tyrannosaurus. Phil Trans R Soc Lond B 309: 395-460.

DAWLEY RM, ZAWISKIE JM AND COSGRIFF JW. 1979. A rauisuchid thecodont from the Upper Triassic Popo Agie Formation of Wyoming. J Vert Paleont 53: 1428-1431. 
DESOJO JB AND ARCUCCI AB. 2009. New material of Luperosuchus fractus (Archosauria: Crurotarsi) from the middle Triassic of Argentina: The earliest known South American rauisuchian. J Vert Paleontol 29: 1311-1315.

DESOJO JB, EZCURRA MD AND SCHULTZ CL. 2011. An unusual new archosauriform from the Middle-Late Triassic of southern Brazil and the monophyly of Doswelliidae. Zool J Linn Soc 161: 839-871.

EWER RF. 1965. The anatomy of the thecodont reptile Euparkeria capensis Brom. Phil Trans R Soc B 248: 379439.

FRANÇA MAG, FERIGOLO J AND LANGER MC. 2011. Associated skeletons of the new middle Triassic "Rauisuchian" from the Brazil. Naturwissenschaften 98: 389-395

FRANÇA MAG, LANGER MC AND FERIGOLO J. 2013. The skull anatomy of Decuriasuchus quartacolonia (Pseudosuchia: Suchia: Loricata) from the middle Triassic of Brazil. Nesbitt SJ, Desojo JB and Irmis RB (Eds), Anatomy, Phylogeny and Paleobiology of Early Archosaurs and their Kin. Geol Soc London Special Publications, $379 \mathrm{p}$.

GALTON PM. 1985. The poposaurid thecodontian Teratosaurus suevicus v. Meyer, plus referred specimens mostly based on prosauropod dinosaur, from the Middle Stubensandstein (Upper Triassic) of Nordwürttemberg. Stutt Beitr Naturkd B 116: 1-29.

GOLOBOFF PA, FARRIS J AND NIXON KC. 2003. TNT: Tree analyses using new technology. Program and Documentation. www.zmuck.dk/public/phylogeny.

GOLOBOFF PA, FARRIS J AND NIXON KC. 2008. TNT, a free program for phylogenetic analysis. Cladistics 24(5): 774-786.

GOWER DJ. 1999. Cranial osteology of a new rauisuchian archosaur from the Middle Triassic of southern Germany. Stutt Beitr Naturkd B 280: 1-49.

GOWER DJ. 2000. Rauisuchian archosaur (Reptilia, Diapsida): An overview. Neues Jahrb Geol Paläontol 218: 447-488.

GRADSTEIN F, OGG J, SCHMITZ M AND OGG G. 2012. The geological time scale 2012. Amsterdam: Elsevier, 1129 p.

HOLLIDAY CM AND WITMER LM. 2008. Cranial kinesis in dinosaurs: intracranial joints, protractor muscles, and their significance for cranial evolution and function in diapsids. J Vert Paleontol 28: 1073-1088.

HORN BLD, MELO TM, SCHULTZ CL, PHILIPP RP, KLOSS HP AND GOLDBERG K. 2014. A new thirdorder sequence stratigraphic framework applied to the Triassic of the Paraná Basin, Rio Grande do Sul, Brazil, based on structural, stratigraphic and paleontological data. J S Am Earth Sci 55: 123-132.

IORDANSKY NN. 1990. Evolution of cranial kinesis in lower Tetrapods. Neth J Zool 40: 32-54.
JUUL L. 1994. The phylogeny of basal archosaurs. Palaeontologia Africana 31: 1-38.

LACERDA MB. 2012. Descrição e estudos de novos espécimes de Prestosuchus chiniquensis (Archosauria, Rauisuchia) do Afloramento "Sanga da Árvore", Município de São Pedro do Sul, região de Xiniquá, Estado do Rio Grande do Sul, Brasil. Programa de Pós-graduação em Geociências. Universidade Federal do Rio Grande do Sul. Dissertação de Mestrado, 157 p. (Unpublished).

LACERDA MB, SCHULTZ LC AND BERTONI-MACHADO C. 2015. First 'Rauisuchian' archosaur (Pseudosuchia, Loricata) for the Middle Triassic Santacruzodon Assemblage Zone (Santa Maria Supersequence), Rio Grande do Sul State, Brazil. Plos One 10(2): e0118563.

LANGER MC. 2004. Basal saurischians. In: Weishampel D, Dodson P and Osmólska H (Org), The Dinosauria. $2^{\text {nd }}$ ed., Berkeley: University of California Press 1: 25-46.

LAUTENSCHLAGER S. 2008. Revision of Rauisuchus tiradentes (Archosauria: Rauisuchia) from the Late Triassic (Carnian) Santa Maria Formation of Brazil and its implications for rauisuchian phylogeny. Department für Geo und Umweltwissenschaften, Ludwing Maximilians Universität, Diplomarbeit, 77 p.

LAUTENSCHLAGER S AND RAUHUT OWM. 2014. Osteology of Rauisuchus tiradentes from the Late Triassic (Carnian) Santa Maria Formation of Brazil, and its implication for rauisuchid anatomy and phylogeny. Zool J Linn Soc 173: 55-91.

LONG RA AND MURRY PA. 1995. Late Triassic (Carnian and Norian) tetrapods from the southwestern United States. N M M N H and Science Bulletin 4: 1-254.

MASTRANTÔNIO BM. 2010. Descrição osteológica de materiais cranianos e pós-cranianos de Prestosuchus chiniquensis (Archosauria, Rauisuchia) do Mesotriássico do RS (Biozona de Dinodontosaurus, Formação Santa Maria) e considerações filogenéticas sobre os rauisúquios. Programa de Pós-graduação em Geociências, Universidade Federal do Rio Grande do Sul. Tese de Doutorado, 244 p.

NESBITT SJ. 2011. The early evolution of archosaurs: Relationships and the origin of major clades. Bulletin of A M N H 352: 1-292.

NESBITT SJ, DESOJO JB AND IRMIS RB. 2013. Anatomy, phylogeny and palaeobiology of early archosaurs and their kin, In: Nesbitt SJ, Desojo JB and Irmis RB (Eds), Anatomy, Phylogeny and Palaeobiology of Early Archosaurs and their Kin. Geol Soc London Spec Publ, 379 p.

NESBITT SJ AND NORELL MA. 2006. Extreme convergence in the body plans of an early suchian (Archosauria) and ornithomimid dinosaurs (Theropoda). Proc R Soc Lond B 273: 1045-1048.

ÖSI A. 2010. Feeding-related characters in basal pterosaurs: implications for jaw mechanism dental function and diet. Lethaia 44: 136-152. 
PARRISH JM. 1993. Phylogeny of Crocodylotarsy, with reference to archosaurian and crurotarsan monophyly. J Vert Paleontol 13: 287-308.

PAVANATTO AEB, MÜLLER RT, DA-ROSA AAS AND DIAS-DA-SILVA S. 2015. New information on the postcranial skeleton of Massetognathus ochagaviae Barberena, 1981 (Eucynodontia, Traversodontidae), from the Middle Triassic of Southern Brazil. Historical Biology: An Inter J Paleo.

RAUGUST T. 2014. Descrição e análise filogenética de um novo material de Rauisuchia (Archosauria, Crurotarsi) da Formação Santa Maria, Triássico Médio Sul-RioGrandense, Brasil. Tese de Doutorado. Universidade Federal do Rio Grande do Sul. Instituto de Geociências. Programa de Pós-Graduação em Geociências, 378 p.

REHOREK SJ, FIRTH BT AND HUTCHINSON MN. 2000. The structure of the nasal chemosensory system in squamate reptiles. 2 Lubricatory capacity of the vomeronasal organ. J Bioscience 1: 181-190.

RIEPPEL O AND ZAHER H. 2001. Re-building the bridge between mosasaurs and snakes. $\mathrm{N} \mathrm{Jb}$ Geol Paläont Abh 221: 111-132.

RUBERT RR AND SCHULTZ CL. 2004. Um novo horizonte de correlação para o Triássico Superior do Rio Grande do Sul. Pesquisas em Geociências 31: 71-88.

SERENO PC. 2005. The logical basis of phylogenetic taxonomy. Syst Biol 54: 595-619.

SERENO PC AND NOVAS FE. 1993. The skull and neck of the basal theropod Herrerasaurus ischigualastensis. J Vert Paleontol 4: 451-476.

SILL WD.1974. The anatomy of Saurosuchus galilei and the relationships of the rauisuchidthecodonts. Bull Mus Comp Zool 7: 317-362.

SOARES MB, SCHULTZ CL AND HORN BLD. 2011. New information on Riograndia guaibensis Bonaparte, Ferigolo \& Ribeiro, 2001 (Eucynodontia, Tritheledontidae) from the Late Triassic of southern Brazil: anatomical and bioestratigraphic implications. An Acad Bras Cienc 83: 329-354.

SULEJ T. 2005. A new rauisuchian reptile (Diapsida: Archosauria) from the Late Triassic of Poland. J Vert Paleontol 25: 78-86.

VERSLUYS J. 1910. Das streptostylie bei Dinosauriern, nebst Bemerkungenüber die Verwandtschaft der Vögel und Dinosaurier. Zoologische Jahrbücher, Abteilungfür Anatomie und Ontogenie der Tiere 30: 175-260.

VERSLUYS J. 1912. Das Streptostylie-Problem und die Bewegungim Schädelbei Sauropsida. Zoologische Jahrbücher, Abteilungfür Anatomie und Ontogenie der Tiere 2(Suppl.15): 545-716.

VERSLUYS J. 1936. Kranium und Visceralskelett der Sauropsiden. 1. Reptilien. 699-808. In: Bolk L, Göppert E, Kallius E and Lubosch W (Eds), Handbuch der vergleicheden Anatomic der Wirbeltiere.V.4. Urban and Schwarzenberg. Berlin.

WEINBAUM JC. 2002. Osteology and relationships of Postosuchus kirkpatricki (Archosauria: Crurotarsi). Texas Tech University, Lubbock, Texas, M.S. thesis, 78 p.

WEINBAUM JC. 2011. The skull of Postosuchus kirkpatricki (Archosauria: Paracrocodyliformes) from the Upper Triassic of the United States. PaleoBios 30: 18-44.

WITMER LM. 1995. Homology of facial structures in extant archosaurs (birds and crocodilians) with the special reference to paranasal pneumaticity and nasal conchae. J Morphol 225: 269-327.

ZERFASS H, LAVINA EL, SCHULTZ CL, GARCIA AJV, FACCINI UF AND CHEMALE Jr F. 2003. Sequence stratigraphy of continental Triassic strata of Southernmost Brazil: a contribution to Southwestern Gondwana paleogeography and paleoclimate. Sediment Geol 161: 85-105.

ZERFASS H, SANDER A and FLORES AE. 2007. Agudo, Folha SH.22-V.C.V, escala 1:100.000, Rio Grande do Sul. Serviço Geológico do Brasil (CPRM), Brasília, 97 p.

\section{APPENDIX I}

\section{ADDITIONAL CHARACTER DESCRIPTION AND CODIFICATION}

414. Dorsoventral position of the subnarial foramen: (0) in middle height regarding the maxillary body, not reaching the ascendant process; (1) above the middle height of the main body of the maxilla, reaching at least the base of the ascendant process.

Mesosuchus browni (-), Prolacerta broomi (-), Proterosuchus fergusi (-), Erythrosuchus africanus (0), Vancleavea campi (-), Chanaresuchus bonapartei (-), Tropidosuchus romeri (-), Euparkeria capensis (-), Parasuchus hislopi (-), Smilosuchus gregorii (-), Pseudopalatus pristinus (-), Gracilisuchusstipanicicorum(-), Turfanosuchus dabanensis (-), Yonghesuchus sangbiensis (-), Ornithosuchus longidens (-), Riojasuchus tenuisceps (-), Revueltosaurus callenderi (?), Stagonolepis robertsoni (-), Aetosaurus ferratus (-), Longosuchus meadei (-), Ticinosuchus ferox (?), Qianosuchus mixtus (0), Xilousuchus sapingensis (?), Arizonasaurus babbitti (?), Poposaurus gracilis holotype (?), Poposaurus gracilis yale (?), 
Lotosaurus adentus (0), Sillosuchus longicervix (?), Effigia okeeffeae (0), Shuvosaurus inexpectatus (0), Prestosuchus chiniquensis (1), Saurosuchus galilei (1), Batrachotomus kuperferzellensis (0), Fasolasuchus tenax (0), Rauisuchus triradentes (?), Polonosuchus silesiacus (?), Postosuchus kirkpatricki (0), Postosuchus alisonae (?), CM 73372 (?), Hesperosuchus agilis (?), Dromicosuchus grallator (-), Hesperosuchus agilis (-), Dibothrosuchus elaphros (?), Terrestrisuchus gracilis (-), Sphenosuchus acutus (-), Litargosuchus leptorhynchus (-), Kayentasuchus walker (-), Orthosuchus stormbergi (?), Alligator mississippiensis (-), Protosuchus haughtoni (-), Protosuchus richardsoni (-),
Eudimorphodon ranzii (-), Dimorphodon macronyx (?), Lagerpeton chanarensis (?), Dromomeron gregorii (?), Dromomeron romeri (?), Marasuchus lilloensis (?), Asilisaurus kongwe (?), Eucoelophysis baldwini (?), Sacisaurus agudoensis (?), Lewisuchus/Pseudolagosuchus (?), Eocursor parvus (?), Silesaurus opolensis (-), Pisanosaurus mertii (?), Heterodontosaurus tucki (-), Lesothosaurus diagnosticus (-), Scutellosaurus lawleri (?), Herrerasaurus ischigualastensis (1), Staurikosaurus pricei (?), Eoraptor lunensis (-), Saturnalia tupiniquim (?), Plateosaurus engelhardti (-), Efraasia minor (-), Tawa hallae (?), Coelophysis bauri (-), Dilophosaurus wetherelli (?), Allosaurus fragilis (-), Velociraptor mongoliensis (-). 